\title{
PEMBERIAN MP- ASI TIDAK BERHUBUNGAN DENGAN KEJADIAN STUNTING PADA ANAK USIA 1- 3 TAHUN DI WILAYAH KERJA PUSKESMAS SUMBANG I KABUPATEN BANYUMAS
}

\author{
${ }^{1}$ Sawitri Dewi, ${ }^{2}$ Ikhwah Mu'minah. \\ ${ }^{1}$ Program Studi Kebidanan DIII, Universitas Muhammadiyah Purwokerto, sawitridewi79@gmail.com \\ ${ }^{2}$ Program Studi Kebidanan DIII, Universitas MuhammadiyahPurwokerto, ikhwahnanda@gmail.com
}

\begin{abstract}
ABSTRAK
Stunting merupakan masalah gizi kronik, artinya keadaan ini muncul sebagai akibat kekurangan gizi yang terakumulasi dalam waktu yang cukup lama. Usia 0-24 bulan merupakan masa kritis dalam pertumbuhan dan perkembangan anak, karena dimasa inilah periode anak yang paling optimal baik untuk intelegensi maupun fisiknya. WHO/UNICEF merekomendasikan 4 hal penting yang harus dilakukan yaitu : pertama memberikan ASI kepada bayi segera dalam 30 menit setelah lahir, kedua memberikan hanya ASI saja atau ASI Eksklusif sampai bayi berusia 6 bulan, ketiga memberikan makanan pendamping ASI (MP- ASI) sejak bayi berusia 6- 24 bulan dan keempat meneruskan pemberian ASI sampai anak berusia 24 bulan atau lebih. Tujuan penelitian ini adalah untuk menganalisis hubungan pemberian ASI Eksklusif dan pemberian MP- ASI, pendapatan dan pendidikan ibu terhadap kejadian stunting di Wilayah Kerja Puskesmas Sumbang I Kabupaten Banyumas.

Penelitian ini merupakan deskriptif analitik menggunakan desain cross sectional. Populasi dan sampel adalah semua balita usia 12- 36 bulan yang ada di wilayah kerja Puskesmas Sumbang I. Sampel diperoleh dengan metode purposive sampling. Metode pengumpulan data dengan pengisian kuesioner mengenai riwayat pemberian ASI Eksklusif, MP-ASI dan pendidikan serta pendapatan orang tua. Data stunting diperoleh dengan melakukan pengukuran tinggi badan balita menggunakan Microtoice yang dibandingkan dengan usia balita.

Hasil penelitian menunjukkan tidak terdapat hubungan yang signifikan antara pemberian ASI Eksklusif $(p=0,372)$, pemberian MP- ASI $(p=0,823)$, tingkat pendidikan $(p=0,979)$ dan pendapatan keluarga $(p=0,13)$ terhadap kejadian stunting di Wilayah Kerja Puskesmas Sumbang I Kabupaten Banyumas dan keseluruhan variabel bukan merupakan faktor risiko kejadian stunting.
\end{abstract}

Kata Kunci :Stunting, ASI Eksklusif, MP- ASI, Pendidikan, Pendapatan Keluarga

ABSTRACT
Stunting is a chronic nutritional problem, meaning that this situation increase as a result of nutritional deficiencies that have accumulated over a long period of time. Age 0-24 months is a critical period in the growth and development of children, because this is the period of the most optimal period of child both for intelligence and physical. WHO / UNICEF recommends 4 important things that must be done, they are: first giving milk to the baby immediately within 30 minutes after birth, second giving only breast milk or exclusive breastfeeding until the baby is 6 months old, third giving complementary feeding (MP-ASI) since the baby aged 6-24 months and fourth continue breastfeeding until the child is 24 months or older. The purpose of this study was to analyze the relationship between Exclusive breastfeeding and complementary feeding (MP-ASI), maternal income and education to the incidence of stunting in the Sumbang I Puskesmas Kabupaten Banyumas.

This research is a descriptive analytic using cross sectional design. The population and sample are all children under the age of 12-36 months in the working area of the Puskesmas Sumbang I. Samples were obtained by purposive sampling method. Data collection methods by filling out questionnaires regarding the history of exclusive breastfeeding, MP-ASI and education and income of parents. Stunting data were obtained by measuring the height of a toddler using Microtoice compared to toddler age.

The results showed no significant relationship between exclusive breastfeeding $(p=0.372)$, MP-ASI $(p=0.823)$, education level $(p=0.979)$ and family income $(p=0.13)$ to the incidence of stunting in the region of Puskesmas Sumbang I in Kabupaten Banyumas and all variables are not risk factors for stunting.

Key Words : Stunting, Eksklusif Breasfeeding, Complementary Feeding (MP-ASI), Education, Family Income. 


\section{PENDAHULUAN}

Rencana pembangunan jangka Menengah Nasional 2010- 2014, perbaikan status gizi masyarakat merupakan salah satu prioritas dengan menurunkan prevalensi balita gizi kurang (underweight) menjadi $15 \%$ dan prevalensi balita pendek (stunting) menjadi 32\% pada tahun 2014 (Kementrian Kesehatan RI, 2015). Hasil Riskesdas tahun 2013 menunjukkan bahwa angka kejadian stunting meningkat menjadi 37,2\% (Kementrian Kesehatan RI, 2016). Hal ini menyebabkan pemerintah kemudian melakukan beberapa strategi sebagai upaya mengatasi permasalahan stunting, salah satunya adalah melalui Gerakan Nasional percepatan Perbaikan Gizi yang tertuang dalam Peraturan Pemerintah No. 42 Tahun 2013. Dalam gerakan ini, pemerintah berupaya untuk fokus penanganan stunting dalam 1000 hari pertama kehidupan (terhitung sejak konsepsi sampai dengan anak berusia 2 tahun) secara terintegrasi, karena masalah gizi tidak hanya dapat diselesaikan oleh sektor kesehatan saja tetapi juga dari sektor luar kesehatan (Kementrian Kesehatan RI, 2015).

Global Strategy for Infant and Young Child Feding, WHO/UNICEF merekomendasikan 4 hal penting yang harus dilakukan yaitu : pertama memberikan Air Susu Ibu (ASI) kepada bayi segera dalam 30 menit setelah bayi lahir, kedua memberikan hanya ASI saja atau pemberian ASI secara Eksklusif sejak lahir sampai bayi berusia 6 bulan, ketiga memberikan makanan pendamping ASI (MPASI) sejak bayi berusia 6- 24 bulan dan keempat meneruskan pemberian ASI sampai anak berusia 24 bulan atau lebih (WHO, 2003). Berdasarkan hasil penelitian yang dilakukan oleh Fikadu, dkk, 2014 menyatakan bahwa seorang anak yang diberikan ASI kurang dari 2 tahun berisiko 5 kali lebih besar mengalami stunting dibandingkan anak yang diberikan ASI lebih dari 2 tahun, selain itu anak- anak yang diberikan ASI Eksklusif kurang dari 6 bulan berisiko 3 kali lipat untuk mengalami stunting dibandingkan anak- anak yang diberikan ASI Eksklusif.

Menurut penelitian yang dilakukan oleh Khazanah Dwi, P., dkk. (2016) menyatakan bahwa terdapat hubungan yang bermakna antara waktu pemberian dan status gizi anak, dalam penelitian tersebut menyatakan bahwa anak- anak yang diberikan MP- ASI tidak sesuai dengan waktu pemberian memiliki risiko 2 kali lipat mengalami stunting. Kabupaten Banyumas merupakan salah satu wilayah yang termasuk dalam kategori 100 Kabupaten/ Kota Prioritas Untuk Intervensi
Anak Kerdil (stunting) yang diselenggarakan oleh Tim Nasional Percepatan Penanggulangan Kemiskinan, yang menunjukkan bahwa prevalensi kejadian stunting di Kabupaten Banyumas pada tahun 2013 sebesar 33,49\% dan jumlah balita yang mengalami stunting sebanyak 49.138 anak (TNP2K, 2017). Berdasarkan banyaknya kasus stunting yang terjadi di Kabupaten Banyumas saat ini, maka penulis ingin mengetahui "Hubungan Pemberian Makanan Pendamping ASI (MPASI) dengan Status Gizi Anak Usia 1- 3 Tahun Di Wilayah Kerja Puskesmas Kembaran II Kabupaten Banyumas."

Penelitian ini bertujuan menganalisis hubungan pemberian ASI Eksklusif, pemberian MP- ASI, pendapatan dan pendidikan orang tua dengan kejadian stunting di Wilayah Puskesmas Sumbang I Kabupaten Banyumas.

\section{TINJAUAN PUSTAKA}

Stunting adalah kondisi gagal tumbuh pada anak balita (bayi dibawah lima tahun) akibat dari kekurangan gizi kronis sehingga anak terlalu pendek untuk usianya (Tim Nasional Percepatan Penanggulangan Kemiskinan, 2017). Menurut Kementrian Kesehatan RI stunting adalah anak balita dengan $\mathrm{Z}$ - score kurang dari -2 SD (stunted) dan kurang dari -3 SD (severely stunted) (Kementrian Kesehatan RI, 2016).

Stunting disebabkan oleh faktor multi dimensi dan tidak hanya disebabkan oleh faktor gizi buruk yang dialami oleh ibu hamil maupun anak balita beberapa faktor penyebab stunting antara lain : praktek pengasuhan yang kurang baik, mash terbatasnya layanan kesehatan termasuk layanan ANC (Antenatal Care), Post Natal Care dan pembelajaran dini yang berkualitas, masih kurangnya akses rumah tangga/ keluarga ke makanan bergizi, dan kurangnya akses air bersih dan sanitasi (Kementrian Desa, Pembangunan Daerah Tertinggal dan Transmigrasi, 2017).

ASI Eksklusif adalah pemberian ASI tanpa tambahan cairan seperti susu formula, jeruk, madu, air the, air putih dan tanpa bahan makanan padat seperti pisang, papaya, bubur susu, biscuit, bubur nasi dan nasi tim (Roesli, 2009). MP-ASI adalah makanan atau minuman yang mengandung zat gizi yang diberikan pada bayi atau naka usia 6- 24 bulan guna memenuhi kebutuhan gizi selain ASI (Depkes, 2006).

MP- ASI merupakan makanan peralihan dari ASI ke makanan keluarga.Pengenalan dan pemberian MP- ASI harus dilakukan secara 
bertahap baik bentuk maupun jumlahnya sesuai dengan kemampuan bayi.Pemberian MP- ASI yang cukup kualitas dan kuantitasnya penting untuk pertumbuhan fisik dan perkembangan kecerdasan anak yang sangat pesat pada periode ini, tetapi sangat diperlukan hygienitas dalam pemberian MP- ASI tersebut (Winarno FG., 1987).Menurut Depkes RI (2006) jenis MP- ASI antara lain makanan tambahan pendamping ASI local (MP- ASI Lokal) dan makanan tambahan pendamping ASI pabrikan.

Menurut Chomaria (2014), MP- ASI harus diberikan pada saat bayi umur 6 bulan, karena :

1. Bayi mengalami growth-spurt (percepatan pertumbuhan) pada usia 3- 4 bulan, bayi mengalami peningkatan nafsu makan, tetapi bukan berarti pada saat umur tersebut bayi siap untuk menerima makanan padat.

2. 0- 6 bulan, kebutuhan bayi bisa dipenuhi hanya dengan mengkonsumsi ASI

3. Umumnya bayi telah siap dengan makanan padat pada usia 6 bulan karena pada usia ini, ASI hanya memenuhi 60- $70 \%$ kebutuhan gizi ibu.

4. Tidak dianjurkan untuk memperkenalkan makanan semi padat atau pada padat pada bayi usia 4- 6 bulan karena system pencernaan mereka belum siap menerima makanan ini.

5. Pemberian makanan sebelum usia 6 bulan, meningkatkan risiko alergi, obesitas, mengurangi minat terhadap ASI

6. Masa aktifnya reflex extrusion yaitu bayi akan mengeluarkan makanan yang ibu sodorkan kemulutnya, ini meningkatkan risiko tersedak jika diberikan makanan padat terlalu dini.

\section{METODE}

Desain dalam penelitian ini menggunakan desain cross sectional. Populasi penelitian ini adalah seluruh ibu danbalita usia 12- 36 bulan yang ada di wilayah kerja Puskesmas Sumbang I, jumlah sampel yang digunakan sebanyak 57 responden dengan tehnik pengambilan sampel Non- probability sampling dengan metode purposive sampling. Pengambilan data dilakukan pada bulan April sampai dengan Juni 2019.

Metode pengumpulan data pada penelitian ini adalah dengan pengisian kuesioner mengenai riwayat pemberian ASI Eksklusif, MP- ASI dan pendidikan serta pendapatan orang tua. Adapun data tentang stunting diperoleh dengan melakukan pengukuran tinggi badan balita menggunakan Microtoice yang kemudian dibandingkan dengan usia balita. Data sekunder berupa data jumlah balita dan status gizi balita di wilayah kerja Puskesmas Kembaran II tahun 2018.Analisis data dilakukan melalui analisa univariat dan bivariat menggunakan analisis Chi-Square.

\section{HASIL DAN PEMBAHASAN}

Berdasarkan hasil pada tabel 1 menunjukkan bahwa sebagian besar ibu $(77,2 \%)$ memiliki tingkat pendidikan rendah, dan lebih dari separuh keluarga mempunyai pendapatan kurang dari 1,1 juta (54.4\%). Pada umumnya anak balita mendapatkan ASI Eksklusif $(66,7 \%)$ dan diberikan MP- ASI pada usia lebih dari 7 bulan $(66,7 \%)$. Mayoritas anak mengalami stunting $(77,2 \%)$.

Tabel 1.

Karakteristik Responden

\begin{tabular}{lll}
\hline \multicolumn{1}{c}{ Karkteristik } & N & \% \\
\hline Pendidikan & & \\
SD- SMP & 44 & 77.2 \\
SMA- PT & 13 & 22.8 \\
$\begin{array}{l}\text { Pendapatan } \\
<1.1 \text { juta }\end{array}$ & 31 & 54.4 \\
$\begin{array}{l}\text { 1.1 juta } \\
\text { ASI Eksklusif }\end{array}$ & 26 & 45.6 \\
Tidak ASI & 38 & 66.7 \\
$\begin{array}{l}\text { Eksklusif } \\
\text { ASI Eksklusif }\end{array}$ & 19 & 33.3 \\
$\begin{array}{l}\text { MP- ASI } \\
<7 \text { bulan }\end{array}$ & 19 & 33.3 \\
$\begin{array}{l}\text { Z bulan } \\
\text { Status Gizi }\end{array}$ & 38 & 66.7 \\
$\begin{array}{l}\text { Tidak Stunting } \\
\text { Stunting }\end{array}$ & 13 & 22.8 \\
\hline
\end{tabular}


Tabel 2.

Hubungan ASI Eksklusif, MP- ASI, Pekerjaan dengan Status Gizi Balita Usia 0- 36 Bulan

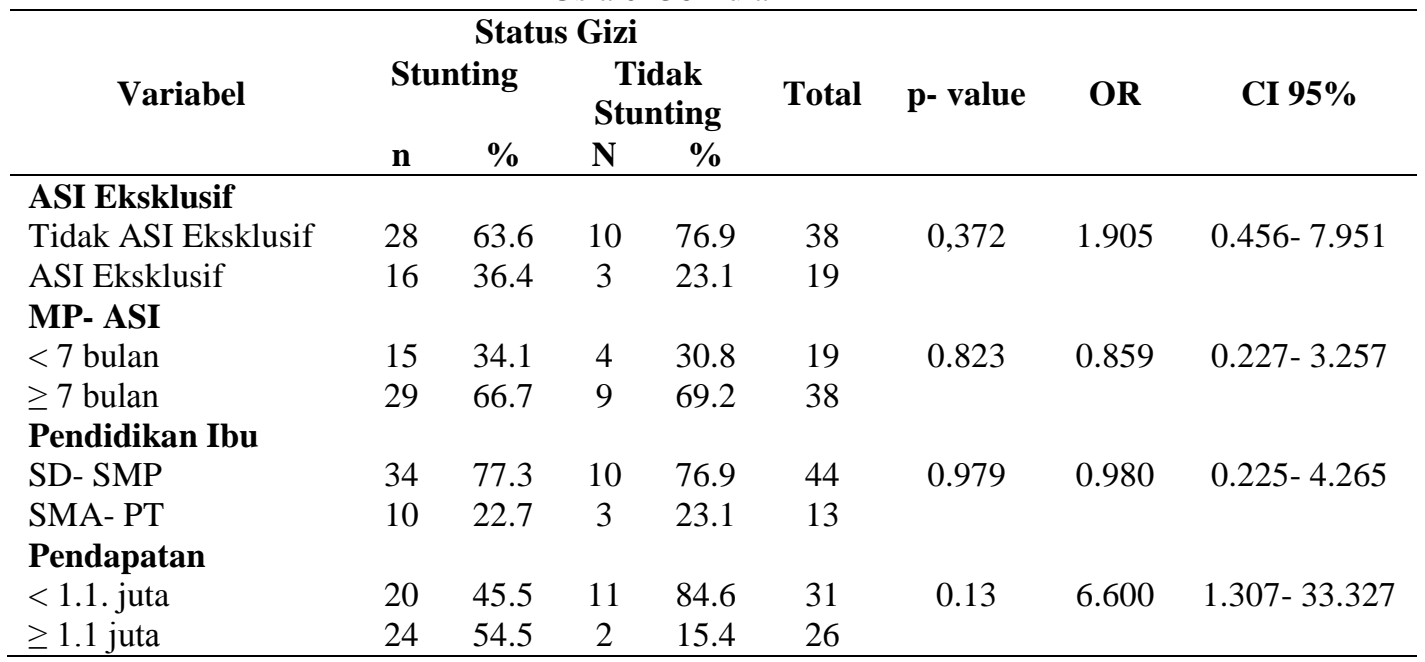

Berdasarkan tabel 2. menunjukkan bahwa variabel ASI Eksklusif, Pemberian MP- ASI, pendidikan ibu dan pendapatan tidak memiliki hubungan yang bermakna dengan kejadian stunting pada anak usia 1- 3 tahun di Wilayah Kerja Puskesmas I Sumbang. Selain itu, dari keseluruhan variable bukan merupakan faktor risiko kejadian stunting.

\section{Hubungan Pemberian ASI Eksklusif dengan Kejadian Stunting}

Hasil analisis hubungan pemberian ASI Eksklusif tidak menunjukkan adanya hubungan yang signifikan dengan kejadian stunting pada anak balita usia 0- 36 bulan di Wilayah Kerja Puskesmas I Sumbang Kabupaten Banyumas.

Penelitian ini sesuai dengan penelitian yang dilakukan oleh Vaozia (2016) yang menyatakan bahwa riwayat pemberian ASI Eksklusif bukan merupakan faktor risiko kejadian stunting pada anak usia 1- 3 tahun di Desa Menduran Kecamatan Brati Kabupaten Grobogan. Ini dapat terjadi dikarenakan dari kualitas ASI itu sendiri atau faktor lain seperti kecukupuan gizi dalam menu sehari- hari untuk anak. Hal ini didukung dengan teori yang menyatakan bahwa ASI Eksklusif bukan merupakan satu- satunya faktor yang mempengaruhi kejadian stunting terdapat faktor lain seperti asupan gizi, penyakit infeksi, ketersediaan pangan, status gizi ibu hamil, berat badan lahir, panjang badan lahir dan MP- ASI (Kemenkes RI, 2015).

Hasil penelitian yang dilakukan oleh Paramashanti (2015) memperoleh hasil yang sama,menyatakan bahwa pemberian ASI Eksklusif bersifat protektif terhadap kejadian stunting, akan tetapi tidak didukung dengan hasil yang signifikan.

Pada penelitian ini, klasifikasi ASI Eksklusif hanya berdasarkan pada data sekunder yang meliputi informasi pemberian ASI Eksklusif atau tidak Eksklusif, sehingga tidak dapat memberikan gambaran perbedaan antara pemberian ASI Eksklusif dari lamanya (prolonged exclusive breasfeeding) dan pemberian ASI Eksklusif hingga 6 bulan saja.

\section{Hubungan Riwayat Pemberian Makanan Pendamping ASI (MP- ASI) dengan Kejadian Stunting}

Berdasarkan hasil penelitian, riwayat pemberian Makanan Pendamping ASI (MP- ASI) tidak terdapat hubungan yang signifikan terhadap kejadian stunting $(\mathrm{p}=0.823)$.

Hal ini sesuai dengan hasil penelitian yang dilakukan oleh Nai (2014) yang menyatakan bahwa tidak ada tren linier yang signifikan antara tingkatan usia pengenalan MP- ASI dan frekuensi pemberian MP- ASI bukan merupakan faktor risiko kejadian stunting (OR 1,07, CI 0,65-1, 76). Pemberian MP- ASI pada usia yang tidak sesuai pada anak yang tidak diberikan ASI lagi mempunyai risiko 1,6 kali lebih besar untuk mengalami stunting dibandingkan anak- anak yang diberikan MP- ASi pada usia yang sesuai.

Hasil penelitian ini sejalan dengan penelitian yang dilakukan oleh Dwitama (2018) yang menyatakan bahwa tidak terdapat hubungan yang signifikan antara pemberian MP- ASI dengan kejadian balita pendek di Kecamatan Jatinangor ( $>$ > 0,05). Proses pertumbuhan linier dipengaruhi oleh defisiensi vitamin A dan zink, dengan demikian perlu dilakukan pengecekan terhadap 
kecukupan gizi mikro pada balita sebagai salah satu upaya untuk mencegah stunting.

Penelitian ini mengumpukan data berkaitan dengan waktu pemberian makan yaitu kurang dari 7 bulan atau lebih dari 7 bulan, sedangkan menurut Depkes, dalam pemberian makanan bayi perlu diperhatikan ketepatan waktu pemberian, frekuensi, jumlah bahan makanan, dan cara pembuatannya.

\section{Hubungan Tingkat Pendidikan Ibu dengan Kejadian Stunting}

Hasil uji menunjukkan bahwa tingkat pendidikan ibu tidak berhubungan dengan kejadian stunting di Wilayah Kerja Puskesmas Sumbang I Kabupaten Banyumas dan faktor tersebut bukan merupakan faktor risiko terjadinya stunting pada masa balita.

Penelitian ini sejalan dengan hasil penelitian yang dilakukan oleh Ni'mah (2015) yang menyatakan bahwa tidak ada hubungan antara tingkat penddikan ibu dengan kejadian stunting pada balita keluarga miskin di Kecamatan Balen Kabupaten Bojonegoro. Demikian pula dengan hasil penelitian yang dilakukan oleh Anindita (2012) yang menyatakan hal yang sama, bahwa tidak ada hubungan antara tingkat pendidikan ibu dengan stunting pada balita.

Indeks BB/ TB merupakan refleksi dari status gizi pada saat sekarang, sedangkan indeks TB/ U adalah refleksi status gizi balita pada masa lampau.Tingkat pengetahuan ibu seringkali dihubungkan dengan kemudahan dan kemampuan ibu untuk menerima informasi dari luar. Hal ini kemudian akan berefek kepada pengetahuan seseorang terhadap keehatan terutama gizi sebelum dan selama kehamilan yang dikaitkan dengan kejadian stunting pada anak. Selain itu ada banyak faktor lain yang mempengaruhi terjadinya masalah kurang gizi khususnya stunting.

Dalam penelitian ini, ibu dengan pendidikan dasar (SD- SMP) sebagian besar memiliki anak dengan stunting demikian pula dengan ibu dengan tingkat pendidikan lanjut (SMA- PT) juga memiliki anak dengan stunting. Hal ini menunjukkan bahwa tingkat pengetahuan tidak memiliki hubungan dengan kejadian stunting pada balita di KecamatanSumbang Kabupaten Banyumas.

Ibu dengan tingkat pengetahuan yang baik diharapkan mampu mengaplikasikan pengetahuan yang dimiliki dalam kehidupan sehari- hari.Namun, perilaku selain dipengaruhi oleh tingkat pengetahuan juga dipengaruhi oleh faktor social ekonomi, social budaya dan lingkungan (Notoatmojo, 2005).

\section{Hubungan PendapatanKeluarga dengan Kejadian Stunting}

Berdasarkan hasil penelitian diperoleh nilai $\mathrm{p}=$ $0,13$ ( $\mathrm{p}>0.05)$, dengan demikian dapat disimpulkan tidak ada hubungan antara tingkat pendapatan keluarga dengan kejadian stunting pada balita di Kecamatan Sumbang Kabupaten Banyumas.

Penelitian yang dilakukan oleh Anindita (2012) menguraikan bahwa tidak ada hubungan antara tingkat pendapatan keluarga dengan kejadian stunting pada balita usia 6- 36 bulan di Kecamatan Tembalang Kota Semarang, apabila keluarga dengan pendapatan yang rendah mampu mengelola makanan yang bergizi dengan bahan yang sederhana dan murah maka pertumbuhan bayi juga akan menjadi baik. Pendapatan yang diperoleh tidak sepenuhnya dibelanjakan untuk kebutuhan makanan pokok, tetapi juga untuk kebutuhan yang lain.

Hasil penelitian yang sama diperoleh dari penelitian yang dilakukan oleh Hapsari (2018) yang menyatakan bahwa pendapatan keluarga tidak memiiki hubungan yang signifikan terhadap kejadian stunting pada balita usia 1259 bulan di wilayah kerja Puskesmas Banyudono II. Tingkat pendapatan yang tinggi belum tentu menjamin status gizi baik pada balita, karena tingkat pendapatan tinggi belum tentu teralokasikan cukup untuk keperluan makan dan pemenuhan gizi. Pendapatan keluarga bukan menjadi faktor risiko penyebab kejadian stunting pada balita, ada banyak faktor lain seperti jumlah anggota keluarga, pola asuh dan pengetahuan dalam mengolah makanan.

\section{KESIMPULAN}

Berdasarkan hasil penelitian diperoleh kesimpulan bahwa kejadian stunting di Wilayah Kerja Puskesmas Sumbang I Kabupaten Banyumas tidak terdapat hubungan dengan pemberian ASI Eksklusif, pemberian MP- ASI dan tingkat pendidikan ibu serta pendapatan keluarga. Perlu dilakukan upaya promosi dan motivasi oleh tenaga kesehatan khususnya bidan desa bekerjasama dengan kader untuk pelaksanaan kegiatan posyandu supaya lebih ditingkatkan sebagai salah satu upaya tindakan skrining kejadian stunting dan pemantauan terhadap bayi dan balita terutama pengukuran panjang badan berdasarkan usia.

\section{DAFTAR PUSTAKA}

Al- Rahmad, Agus Hendra, Ampera Miko, Abdul Hadi, 2013, Kajian Stunting Pada Anak Balita Ditinjau Dari Pemberian ASI Eksklusi, MP- ASI, Status Imunisasi Dan Karakteristik Keluarga Di Kota Banda Aceh,Jurnal Kesehatan Ilmiah Nasuwakes, Vol. 6, Banda Aceh.

Anindita, Putri, 2012, Hubungan Tingkat Pendidikan Ibu, Pendapatan Keluarga, Kecukupan Protein \& Zinc Dengan Stunting (Pendek) Pada Balita Usia 635 Bulan Di Kecamatan Tembalang Kota Semarang, Jurnal Kesehatan 
Masyarakat, Vol. 1, No. 2, Tahun 2012, Hal. 617-626, Semarang.

Chomaria, Nurul, 2014, MenuTerlengkap MPASI, Surakarta.

Depkes RI. 2006. Pedoman Umum Pemberian Makanan Pendamping Air Susu Ibu (MP-ASI) Lokal. Program Perbaikan Gizi Masyarakat.

Dwitama,Subandra Yogi, Yenni Zuhairini, Julitio Djais, 2018, Hubungan Pemberian ASI Eksklusif Dan makanan Pendamping ASI Terhadap Balita Pendek Usia 2 Sampai 5 Tahun Di Kecamatan Jatinangor, JSK, Volume 3, Nomor 3, Maret tahun 2018. Bandung.

Fikadu, Teshale, Sahilu Assegid and Lamessa Dube, 2014, Factors Associated With Stunting Among Children of Age 24 to 59 Months in Meskan District, Gurage Zone, SouthEthiopia: a case- control study, BMC Public- Health, Vol. 14.

Hapsari, Windi, 2018, Hubungan pendapatan Keluarga, Pengetahuan Ibu Tentang Gizi, Tinggi Badan Orang Tua, Dan Tingkat Pendidikan Ayah Dengan Kejadian StuntingPada Anak Umur 1259 Bulan, Skripsi. Surakarta : Fakultas Kedokteran Universitas Muhammadiyah Surakarta.

Indrawati, Sri, 2016, Hubungan Pemberian ASI Eksklusif Dengan Kejadian Stunting Pada Anak Usia 2- 3 Tahun Di Desa Karangrejek Wonosari Gunungkidul, Skripsi. Yogyakarta: Fakultas Ilmu Kesehatan Universitas 'Aisyiyah Yogyakarta.

Kementrian Desa, Pembangunan Daerah Tertinggal dan Transmigrasi, 2017, Buku Saku Desa dalam Penanganan Stunting, Jakarta.

Kementrian Kesehatan RI, 2015, Rencana Strategis Kementrian Kesehatan Tahun 2015- 2019, Jakarta.

Kementrian Kesehatan RI, 2016, Pedoman Umum Program Indonesia Sehat Dengan Pendekatan Keluarga, Jakarta.

Khasanah, Dwi Puji, Hamam Hadi, Bunga Astria Paramashanti, 2016, Waktu Pemberian Makanan Pendamping ASI (MP-ASI) Berhubungan Dengan Kejadian Stunting Anak Usia 6- 23 bulan di Kecamatan Sedayu, Jurnal Gizi dan Dietetik Indonesia, Vol. 4, No.2, Yogyakarta.

Kurnia, R., 2012, Dampak Anak Kurang Gizi Diakses dari http://www.tempo.co/ $\mathrm{read} / \mathrm{news} / 2012 / 09 / 24 / 060431529 / \mathrm{Dam}$ pak Anak Kurang Gizi.

Kristiansari, W., 2009, ASI Menyusui dan Sadari, Yogyakarta: Nuha Medika.

Nai, Hildagardis. M. E, Made Alit Gunawan, Esti Nurwanti, 2014, Praktik Pemberian
Makanan Pendamping ASI (MP- ASI) Bukan Faktor Risiko Kejadian Stunting Pada Anak Usia 6- 23 Bulan, Jurnal Gizi Dan Dietetik Indonesia, Vol. 2, No. 3, September 2014: 126- 139.

Ni'mah, Cholifatun, Lailatul Muniroh, 2015, Hubungan Tingkat Pendidikan, Tingkat Pengetahuan dan Pola Asuh Ibu Dengan Wasting Dan Stunting Pada Balita Keluarga Miskin, Media Gizi Indonesia, Vol. 10, No. 1. Tahun 2018, Hal. 84- 90. Surabaya.

Notoatmodjo, 2005, Pendidikan dan Perilaku Kesehatan, Jakarta: Rineka Cipta

Paramashanti, Bunga Astria, 2015, Pemberian ASI Eksklusif Tidak Berhubungan Dengan Stunting Pada Anak Usia 6- 23 Bulan di Indonesia, Jurnal Gizi Dan Dietetik Indonesia, Vol. 3, No. 3, September, 2015, Hal. 162- 174.

Rahmayana, Irviani A. Ibrahim, Dwi Santy Damayati, 2014, Hubungan Pola Asuh Ibu Dengan Kejadian Stunting Anak Usia 24- 59 Bulan Di Posyandu Asoka II Wilayah Pesisir Kelurahan Barombong Kecamatan Tamalate Kota Makassar Tahun 2014, Al- Shihah: Public Health Science Journal, Vol. VI, No. 2. Makassar.

Roesli, U., 2009, Inisiasi Menyusui Dini Plus ASI Eksklusif, Jakarta: Pustaka Bunda.

Suradi \& Kristina (Ed), 2004, Manajemen Laktasi Cetakan ke- 2, Jakarta: Program Manajemen Laktasi Perkumpulan Perinatologi Indonesia.

Soetjiningsih, 1995, Tumbuh Kembang Anak, Jakarta: EGC.

Tim Nasional Percepatan Penanggulangan Kemiskinan, 2017, Ringkasan 100 Kabupaten/ Kota Prioritas Untuk Intervensi Anak Kerdil (Stunting), Cetakan I, Agustus.

Vaozia, Syifa \& Nuryanto, 2016, Faktor Risiko Kejadian Stunting Pada Anak Usia 1 - 3 Tahun (Studi Di Desa Menduran Kecamatan Brati Kabupaten Grobogan), Jurnal of Nutrition College, Vol. 5, No. 4,. Hal. 314- 320

WHO, 2003, Global Strategy For Infant And Young Child Feeding, Singapore.

WHO, 2014, WHOGlobal Nutrition Targets 2025; Stunting Policy Brief. 